\title{
Family history of colorectal cancer in Iran
}

\section{Mahboobeh Mahdavinia ${ }^{1}$, Faraz Bishehsari1 ${ }^{1}$ Reza Ansari1, Nasim Norouzbeigi ${ }^{1}$, Ahmad Khaleghinejad ${ }^{2}$, Mahshid Hormazdi ${ }^{3}$, Naser Rakhshani ${ }^{3}$ and Reza Malekzadeh*1}

\begin{abstract}
Address: ${ }^{1}$ Digestive Disease Research Centre (DDRC), Shariati Hospital, Tehran University of Medical sciences, Tehran, Iran, ${ }^{2}$ General surgery ward, Mehr Hospital, Tehran, Iran and ${ }^{3}$ Pathology Department, Mehr Hospital, Tehran, Iran

Email: Mahboobeh Mahdavinia - mahdavi@ddrcir.org; Faraz Bishehsari - bishehsari@ddrcir.org; Reza Ansari - ansarir@ams.ac.ir; Nasim Norouzbeigi - noroozbeigi@ddrcir.org; Ahmad Khaleghinejad - khaleghinejad@ams.ac.ir;

Mahshid Hormazdi - hormazdi_ddrc@yahoo.co.uk; Naser Rakhshani - rakhshani@ddrcir.org; Reza Malekzadeh* - malek@ams.ac.ir

* Corresponding author
\end{abstract}

Published: 05 September 2005

BMC Cancer 2005, 5:II2 doi:10.1/86/I47|-2407-5-II2
Received: 02 May 2005

Accepted: 05 September 2005

This article is available from: http://www.biomedcentral.com/I47/-2407/5/II2

(c) 2005 Mahdavinia et al; licensee BioMed Central Ltd.

This is an Open Access article distributed under the terms of the Creative Commons Attribution License (http://creativecommons.org/licenses/by/2.0), which permits unrestricted use, distribution, and reproduction in any medium, provided the original work is properly cited.

\begin{abstract}
Background: Previous reports show a high proportion of young CRC patients in Iran. In this study we aim to look for the clustering of colorectal cancer in families of a series of CRC patients from Iran.

Methods: The family history of cancer is traced in 449 CRC patients of which 112 were 45 yrs or younger and 337 were older than 45 yrs at time of diagnosis. The patients were admitted in two hospitals in Tehran, during a 4-year period.

Results: Clinical diagnosis of HNPCC was established in 21 (4.7\%) probands. Family history of CRC was more frequently reported by early-onset than by late-onset patients $(29.5 \%$ vs. $12.8 \%$, P $<0.00 \mathrm{I})$.

Distribution of tumor site differed significantly between those with and without family history of CRC. Right colon cancer was the most frequent site $(23 / 45,35.4 \%)$ observed in patients with positive family history of colorectal cancer.

Conclusion: The relatively high frequency of CRC clustering along with HNPCC in our patients should be further confirmed with larger sample size population-based and genetic studies to establish a cost effective molecular screening for the future.
\end{abstract}

\section{Background}

Colorectal carcinoma (CRC) is the third most common cause of cancer related deaths in the world [1] with some well known hereditary forms. Hereditary non-polyposis colorectal cancer (HNPCC) is the most common type of hereditary CRC. The frequency of HNPCC varies worldwide ranging from 1 to $6 \%$ [2]. This variability could be due to discrepancies in definitions (clinical $v s$. molecular criteria) and also regional heterogeneity [3-5].

Apart from defined genetic syndromes of CRC, both retrospective and prospective studies proved that familial history of colorectal cancer could increase a person's lifetime risk of colorectal cancer significantly [6,7]. 
CRC with age-adjusted rate of 6-7.9 per 100,000 person per year is the fourth most common cancer in Iran $[8,9]$. Early-onset colorectal cancer (less than 40 yrs of age at time of diagnosis) comprises almost one fifth of all CRC cases in the country $[9,10]$. This proportion is considerably lower in high-risk countries, with rates ranging from $2 \%$ to $8 \%[11,12]$. The high proportions of young CRC cases seen in Iran, and probably many neighboring countries, are mainly due to the young age-structure of these countries and relatively low rates of CRC in older individuals [10].

Up to now there have been no reports addressing the familial aggregation of colorectal cancer in Iran. In the current study, we aimed to study the clustering of colorectal cancer in families of CRC patients and make a comparison of frequency of colorectal and other types of cancer in family members of early-onset with that of late-onset CRC patients.

\section{Methods}

We reviewed all patients' documents with a pathologically confirmed diagnosis of colorectal adenocarcinoma admitted in two hospitals in Tehran between January 2000 and February 2004. Patients with familial adenomatous polyposis or those with underlying inflammatory bowel disease were excluded. Of 662 patients registered in the database, 174 patients were lost due to change of address or contact phone number, 33 refused to be interviewed and 6 were excluded because of incomplete family history accordingly, 449 CRC cases (112 younger than 45 yrs and 337 older than 45 yrs at diagnosis) or their close family members participated in this study.

Demographic, clinical and tumor-related characteristics of patients were recorded based on their hospital documents. These parameters included gender, age at diagnosis, place and date of birth and tumor-related factors such as location, stage, degree of differentiation and mucus production.

All of these patients or their siblings/parents (in the case the patient was dead or not available) were interviewed to trace their family history of cancer including occurrence of malignancy in the family, type of cancer and the age at diagnosis of the affected family member. Pedigrees were drawn at least up to second-degree relatives. The obtained pedigrees were reconfirmed by interviewing another member of family. In addition, we tried to verify reported malignancies in relatives by asking for their medical records, if available. In Iran, family relations are very strong and people are usually aware of serious diseases such as cancer in their relatives.
Patients belonging to families fulfilling the AmsterdamII criteria, including at least three members with an HNPCCassociated cancer (colorectal, endometrial, small bowel, ureter, renal pelvis) in at least two successive generations, one being a first-degree relative of the other two and at least one diagnosed before the age of 50 years, were classified as HNPCC [13].

Patients from families which did not fulfill Amsterdam criteria but with at least two relatives with colorectal cancer in a first- or second-degree relationship were classified as Hereditary Colorectal Cancer (HCRC).

This study was approved by the Digestive Disease Research Center of Tehran University of Medical Sciences Institutional Review Board and informed consents were obtained from patients or their families participating in the study.

\section{Statistical analysis}

Qualitative variables were compared by chi-squared test with Yates correction when needed. A $P$ value of less than 0.05 was considered to indicate a statistically significant difference. All calculations were performed using the 11.5 SPSS software package (SPSS Inc., Chicago, IL, USA).

\section{Results}

Four-hundred forty nine (449) CRC patients with pathologically confirmed colorectal adenocarcinoma were enrolled in the study.

Tumor sites of early-onset and late-onset group are separately shown in table 1 . No significant difference in localization of tumor was observed between the two groups.

Family history of cancer up to second-degree relatives were observed in $60(53.5 \%)$ of early-onset and 144 (43.5\%) of late-onset patients respectively. The most common cancers affecting first and second degree relatives are shown in table 2 . History of colorectal cancer in at least one relative was significantly more frequent in early-onset patients; 33 (29.5\%) comparing to 43 (12.8\%) cases in late-onset group. Frequency of other types of cancers reported in the family did not differ significantly between the two age groups.

The frequency of hereditary types of colorectal cancer in two age groups is shown in Table 3. Among 21 HNPCC families, nineteen fulfilled the Amsterdam criteria I having at least three members with CRC in two consecutive generations, one being a first-degree relative of the other two and at least one diagnosed before the age of 50 years [14]. The other 2 families fulfilled the Amsterdam criteria II with history of colorectal and endometrial cancer in the family. 
Table I: CRC characteristics among young and old patients.

\begin{tabular}{|c|c|c|c|}
\hline Variable & Early-onset $(n=1 \mid 2)$ & Late-onset $(n=337)$ & P Valuet \\
\hline $\operatorname{Sex}(M / F)$ & $43 / 69$ & $138 / 199$ & NStt \\
\hline \multicolumn{4}{|l|}{ Tumor Location } \\
\hline Right & $30(26.8 \%)$ & $62(18.4 \%)$ & NS \\
\hline Left & $43(38.4 \%)$ & $134(39.8 \%)$ & NS \\
\hline Rectum & $36(32.1 \%)$ & $|4|(4 \mid .8 \%)$ & NS \\
\hline NOS & $3(2.6 \%)$ & 0 & + \\
\hline
\end{tabular}

†Assigns the significance of the differences between two group t† NS: Not significant

Table 2: Frequent cancer sites in relatives of early and late-onset CRC patients.

\begin{tabular}{|c|c|c|c|}
\hline & Early-onset $(n=1 \mid 2)$ & Late-onset $(n=337)$ & P Valuet \\
\hline Family History $(\mathrm{FHx})$ of cancer & $60(53.6 \%)$ & $144(42.7 \%)$ & NStt \\
\hline $\mathrm{FHx}$ of $\mathrm{CRC}$ & $33(29.4 \%)$ & $43(12.8 \%)$ & $<0.001$ \\
\hline Breast & $11(9.8 \%)$ & $17(5 \%)$ & NS \\
\hline Stomach & $9(8 \%)$ & $17(5 \%)$ & NS \\
\hline Lung & $5(4.5 \%)$ & $25(7.5 \%)$ & NS \\
\hline Leukemia \& Lymphoma & $4(3.6 \%)$ & $14(4.2 \%)$ & NS \\
\hline Brain & $4(3.6 \%)$ & $9(2.7 \%)$ & NS \\
\hline Endometrial & $2(1.8 \%)$ & $12(3.6 \%)$ & NS \\
\hline
\end{tabular}

†Assigns the significance of the differences between two group

t† NS: Not significant

Table 3: Hereditary forms of CRC in two age groups.

\begin{tabular}{ccccc}
\hline Variable & $\begin{array}{c}\text { Total } \\
(\mathrm{n}=449)\end{array}$ & $\begin{array}{c}\text { Early-onset } \\
(\mathrm{n}=112)\end{array}$ & $\begin{array}{c}\text { Late-onset } \\
(\mathrm{n}=337)\end{array}$ & $\mathrm{P}$ Valuet \\
\hline HNPCC & $21(4.7 \%)$ & $12(10.7 \%)$ & $9(2.9 \%)$ & $<0.001$ \\
HCRC & $15(3.4 \%)$ & $9(8 \%)$ & $6(1.7 \%)$ & $<0.001$ \\
One first-degree relative & $26(5.8 \%)$ & $7(6 \%)$ & $19(5.6 \%)$ & $\mathrm{NSt+}$ \\
with CRC & & & &
\end{tabular}

†Assigns the significance of the differences between two group

†† NS: Not significant

Distribution of tumor site differed significantly between patients with family history of CRC and those without this history (Table $4, \dagger$ ); In total, right colon cancer was seen more frequently than other locations in probands with family history of CRC, in contrast to higher percentage of left colon carcinoma in patients without this history.

Rectal carcinoma was rarely seen in young patients with positive family history; $12.1 \%$ comparing to $38 \%$ in those without family history ( $\mathrm{p}=0.025)$ or cases belonging to the other age group.

\section{Discussion}

This report represents the first study to characterize the profile of familial CRC aggregation in Iranian patients. Although we tried to include all recorded patients in this study, familial profile of $213(32 \%)$ cases could not be determined and analyzed here (see method). However, there were no significant differences in age, sex and tumor localization of participating and non participating patients.

The estimation of the frequency of HNPCC among CRC patients based on family history varies in different 
Table 4: distribution of tumor sites by family history of colorectal cancer according to age of the proband.

\begin{tabular}{|c|c|c|}
\hline Age group & Positive $\mathrm{FH}^{\dagger}$ of $\mathrm{CRC}$ & Negative $\mathrm{FH}$ of $\mathrm{CRC}$ \\
\hline Totalt & $N=76$ & $N=373$ \\
\hline Righta $^{a}$ & $28(36.9 \%)$ & $66(17.7 \%)$ \\
\hline Left & $24(31.6 \%)$ & $167(44.8 \%)$ \\
\hline Rectum & $22(29 \%)$ & $139(37.3 \%)$ \\
\hline NOS & $2(2.5 \%)$ & $\mathrm{I}(0.03 \%)$ \\
\hline Over 45 & $N=43$ & $N=294$ \\
\hline Right $^{b}$ & |4(32.6\%) & $49(16.7 \%)$ \\
\hline Left & II (25.6\%) & $136(46.3 \%)$ \\
\hline Rectum & $18(4 \mid .8 \%)$ & $109(37.1 \%)$ \\
\hline Less than 45 & $N=33$ & $N=79$ \\
\hline Rightc $^{c}$ & 14(42.4\%) & $17(2 \mid .5 \%)$ \\
\hline Left & $13(39.4 \%)$ & $31(39.2 \%)$ \\
\hline Rectum & $4(12.1 \%)$ & $30(38 \%)$ \\
\hline NOS & $2(6.1 \%)$ & $\mathrm{I}(\mathrm{I} .3 \%)$ \\
\hline
\end{tabular}

$t:$ difference of tumor site distribution between two groups $(p<0.001)$ a,b,c: $\mathrm{p}<0.05$

populations. In a multicenter study on Finnish population, the frequency of families meeting the Amsterdam criteria was $1.7 \%$ [15]. Ponz et al estimated the frequency of HNPCC among CRC cases to be 3.4-4.5\% in Northern Italy [3], while in Spanish population; clinical diagnosis of HNPCC was established in $2.5 \%$ of CRC patients [16]. In a pilot study by Soliman a et al, 7.2\% of Egyptian colorectal patients had family history suggestive of hereditary non polyposis colorectal cancer [17]. Discrepancies in the reported frequency of HNPCC between populations probably reflect population differences. Frequency of this syndrome in Iran has not yet been studied. In our study, a total of 21 cases $(4.7 \%)$ met the Amsterdam criteria II. This relatively high frequency of HNPCC in our patients should be further confirmed with larger sample size, population-based, and genetic studies.

HNPCC clinical diagnosis was significantly more prevalent among younger patients in agreement with previous studies $[18,19]$. In some other studies, the mean age at diagnosis for HNPCC patients was reported to be between $52-60$ yrs $[20,21]$. However, we found that almost $3 \%$ of patients over 45 yrs belonged to families fulfilling Amsterdam criteria. This indicates that taking detailed family history even in old cases is necessary and could identify CRC families with known genetic risk.

Also, we have found higher frequency of familial clustering of CRC apart from HNPCC cases in younger patients (Table 3).This in agreement with studies in other populations, suggests stronger genetic background in younger onset CRC patients [22].
We observed 15 families who did not fulfill HNPCC criteria, but with more than 2 CRC relatives in the family (Table 3). It was previously suggested that some familial cancers might be due to common environmental exposures of family members rather than genetic clustering of cancer [23], but more recently; it has been shown that familial risk for CRC are mainly due to heritable causes [24]. Therefore, these families could be added to HNPCC families to undergo analysis of MMR genes [25]. However, not all CRC clustering could be attributed to defects in genes involved in mismatch repair [26], and unknown loci may be responsible for much of the familial aggregation of CRC [27].

It is suggested that family history of CRC is related to the localization of tumor. Some studies proposed a stronger familial component for proximal than for distal colon cancer $[6,28]$, while this association was not observed in other studies [29]. In our study, right-sided tumors occurred more frequently in patients with positive family history of CRC compared to those without this history (36.9\% vs. $17.7 \%, \mathrm{p}<0.001)$. This pattern was almost the same in patients over and under 45 yrs of age (Table 4 ). Also, we have found rectal cancer to be less frequent among younger probands with positive CRC family history. This is in agrremnet with the previous report of Olsson $\mathrm{L}$ and Lindblom A, in which the frequency of sigmoid cancer was shown to be lower among familial CRC cases compared to sporadic patients [21]. Altogether, these findings could indicate a difference in carcinogenic pathways based on the tumor location with heritable causes mostly affecting the right colon and exogenous factors 
responsible for carcinogenesis in the distal part of the large bowel. It has been suggested that chromosomal instability affecting allelic losses of APC and P53 are more frequent in distal colonic and rectal tumors than in proximal lesions. On the other hand, microsatellite instability is more common in proximal tumors [30].

Appropriate screening strategies should be considered to decrease the burden of CRC in Iran.Our ongoing molecular and genetic studies including analysis of micro satellite instability and mismatch repair gene mutations would most likely help us to characterize the molecular basis for the observed clustering of colorectal cancer among families of younger onset patients and could lead to the adoption of simpler and more cost effective molecular screening in the future.

\section{Conclusion}

Clinical diagnosis of HNPCC was observed in 21 (4.7\%) probands in our study. Familial clustering of CRC was more frequent in younger probands. The right side of the colon was more frequently affected in patients with positive family history of CRC. This indicates that a detailed family history is mandatory in colorectal cancer patients with particular attention to younger onset cases and those with right-sided tumors.

\section{Authors' contributions}

$\mathrm{MM}$ and FB designed and conducted the study, interviewed the patients, analyzed the data, and drafted the manuscript.

RA, NN and AK assisted in conducting the study and interviewing the patients.

$\mathrm{MH}$ and NR reviewed and approved the pathology reports of the patients.

RM supervised the study scientifically, has been involved in designing the study and preparing the manuscript and revising it for scientific content and has given final approval of the version to be published.

All authors read and approved the final manuscript.

\section{Acknowledgements}

We are thankful to Mrs. Mohseni-far for contacting patients, Miss Noroozi in Mehr Hospital for her kind help in reviewing records and Dr. Annette Ratcliff for helping in language correction.

\section{References}

I. Parkin DM: Global cancer statistics in the year 2000. Lancet Oncol 200I, 2:533-43.

2. Lynch HT, de la Chapelle A: Hereditary colorectal cancer. N Engl J Med 2003, 348(1 0):919-32.

3. Ponz de Leon M, Sassatelli R, Benatti P, Roncucci L: Identification of hereditary nonpolyposis colorectal cancer in the general population: the 6-year experience of a population-based registry. Cancer 1993, 71:3493-3501.

4. Rustgi AK: Hereditary gastrointestinal polyposis and nonpolyposis syndromes. N Engl J Med I994, 33 I: |694-I702.

5. Aaltonen LA, Salovaara R, Kristo P, Canzian F, Hemminki A, Peltomaki $P$, Chadwick RB, Kaariainen $H$, Eskelinen $M$, Jarvinen $H$, Mecklin $J P$, de la Chapelle A: Incidence of hereditary nonpolyposis colorectal cancer and the feasibility of molecular screening for the disease. N Engl J Med I998, 338:|48|-| 487.

6. Fuchs CS, Giovannucci EL, Colditz GA, Hunter DJ, Speizer FE, Willett WC: A prospective study of family history and the risk of colorectal cancer. N Engl J Med I994, 33 I(25): I669-74.

7. St John DJ, McDermott FT, Hopper JL, Debney EA, Johnson WR, Hughes ES: Cancer risk in relatives of patients with common colorectal cancer. Ann Intern Med 1993, I I 8:785-790.

8. Sadjadi A, Malekzadeh R, Derakhshan MH, Sepehr A, Nouraie M, Sotoudeh M, Yazdanbod A, Shokoohi B, Mashayekhi A, Arshi S, Majidpour A, Babaei M, Mosavi A, Mohagheghi MA, Alimohammadian M: Cancer occurrence in Ardabil: results of a population-based cancer registry from Iran. Int J Cancer 2003, I 07(I): I | 3-8.

9. Hosseini SV, Izadpanah A, Yarmohammadi H: Epidemiological changes in colorectal cancer in Shiraz, Iran: 1980-2000. ANZ J Surg 2004, 74(7):547-9.

10. Ansari R, Mahdavinia M, Sadjadi A, Nouraie M, Kamangar F, Bishehsari F, Fakheri H, Semnani S, Arshi S, Zahedi MJ, Darvish-Moghadam S, Mansour-Ghanei F, Mosavi A, Malekzadeh R: Incidence and age distribution of colorectal cancer in Iran, results of a population-based cancer registry. Can Lett in press.

II. Griffin PM, Liff JM, Greenberg RS, Clark WS: Adenocarcinomas of the colon and rectum in persons under $\mathbf{4 0}$ years old. A population-based study. Gastroenterology 1991, I00:1033-40.

12. Mitry E, Benhamiche AM, Jouve JL, Clinard F, Finn-Faivre C, Faivre J: Colorectal adenocarcinoma in patients under 45 years of age: comparison with older patients in a well-defined French population. Dis Colon Rectum 200I, 44:380-7.

13. Vasen HF, Watson P, Mecklin JP, Lynch HT: New clinical criteria for hereditary nonpolyposis colorectal cancer (HNPCC, Lynch syndrome) proposed by the International Collaborative group on HNPCC. Gastroenterology 1999, I I 6(6): |453-6.

14. Vasen HF, Mecklin JP, Khan PM, Lynch HT: The International Collaborative Group on Hereditary Non-Polyposis Colorectal Cancer (ICG-HNPCC). Dis Colon Rectum I99I, 34(5):424-5.

15. Mecklin JP, Jarvinen HJ, Hakkiluoto A, Hallikas H, Hiltunen KM, Harkonen N, Kellokumpu I, Laitinen S, Ovaska J, Tulikoura J: Frequency of hereditary nonpolyposis colorectal cancer. A prospective multicenter study in Finland. Dis Colon Rectum 1995, 38:588-93.

16. Pinol V, Andreu M, Castells A, Paya A, Bessa X, Rodrigo J, Gastrointestinal Oncology Group of the Spanish Gastroenterological Association: Frequency of hereditary non-polyposis colorectal cancer and other colorectal cancer familial forms in Spain: a multicentre, prospective, nationwide study. Eur J Gastroenterol Hepatol 2004, I 6(I):39-45.

17. Soliman AS, Bondy ML, Levin B, El-Badawy S, Khaled H, Hablas A, Ismail S, Adly M, Mahgoub KG, McPherson RS, Beasley RP: Familial aggregation of colorectal cancer in Egypt. Int J Cancer 1998, 77(6):8II-8I6.

18. Mecklin JP, Järvinen HJ: Clinical features of colorectal carcinoma in cancer family syndrome. Dis Colon Rectum 1986, 29(3): $160-4$.

19. Lynch HT, Smyrk TC, Watson P, Lanspa SJ, Lynch JF, Lynch PM, Cavalieri RJ, Boland CR: Genetics, natural history, tumor spectrum, and pathology of hereditary nonpolyposis colorectal cancer: an updated review. Gastroenterology 1993, I 04(5): I535-49.

20. Peel DJ, Ziogas A, Fox EA, Gildea M, Laham B, Clements E, Kolodner $\mathrm{RD}$, Anton-Culver $\mathrm{H}$ : Characterization of hereditary nonpolyposis colorectal cancer families from a population-based series of cases. J Natl Cancer Inst 2000, 92( I 8): I5 17-22.

21. Olsson L, Lindblom A: Family history of colorectal cancer in a Sweden county. Fam Cancer 2003, 2(2):87-93.

22. Paraf F, Jothy S: Colorectal cancer before the age of 40: a casecontrol study. Dis Colon Rectum 2000, 43(9): I222-6.

23. Khoury MJ, Beaty TH, Liang K-Y: Can familial aggregation of disease be explained by familial aggregation of environmental risk factors? Am J Epidemiol 1988, 127:674-683. 
24. Hemminki K, Chen B: Familial risk for colorectal cancers are mainly due to heritable causes. Cancer Epidemiol Biomarkers Prev 2004, I 3(7): 1253-6.

25. Vasen HFA: What is hereditary nonpolyposis colorectal cancer (HNPCC). Anticancer Res 1994, 14:1613-1616.

26. Liu B, Parsons R, Papadopoulos N, Nicolaides NC, Lynch HT, Watson P, Jass JR, Dunlop M, Wyllie A, Peltomaki P, de la Chapelle A, Hamilton SR, Vogelstein B, Kinzler KW: Analysis of mismatch repair genes in hereditary non-polyposis colorectal cancer patients. Nat Med 1996, 2:169-74.

27. Lewis CM, Neuhausen SL, Daley D, Black FJ, Swensen J, Burt RW, Cannon-Albright LA, Skolnick MH: Genetic heterogeneity and unmapped genes for colorectal cancer. Cancer Res 1996, 56(6): $1382-8$.

28. Andrieu N, Launoy G, Guillois R, Ory-Paoletti C, Gignoux M: Estimation of the familial relative risk of cancer by site from a French population based family study on colorectal cancer (CCREF study). Gut 2004, 53(9): I322-8.

29. Kee F, Collins BJ: Families at risk of colorectal cancer: who are they? Gut 1992, 33(6):787-90.

30. Lynch HT, de la Chapelle A: Genetic susceptibility to non-polyposis colorectal cancer. J Med Genet I999, 36(II):80I-I8. Review

\section{Pre-publication history}

The pre-publication history for this paper can be accessed here:

http://www.biomedcentral.com/1471-2407/5/112/pre

pub

Publish with Biomed Central and every scientist can read your work free of charge

"BioMed Central will be the most significant development for disseminating the results of biomedical research in our lifetime. "

Sir Paul Nurse, Cancer Research UK

Your research papers will be:

- available free of charge to the entire biomedical community

- peer reviewed and published immediately upon acceptance

- cited in PubMed and archived on PubMed Central

- yours - you keep the copyright

Submit your manuscript here:

http://www.biomedcentral.com/info/publishing_adv.asp
BioMedcentral 